\title{
"A light heart lives long": A new avenue of secondary prevention we must explore
}

\author{
Fraser Douglas Rubens, MD
}

\author{
From the University of Ottawa Heart Institute, Ottawa, Ontario, Canada. \\ Disclosures: Author has nothing to disclose with regard to commercial support. \\ Received for publication July 15, 2017; accepted for publication July 31, 2017; available ahead of print Aug 30, \\ 2017. \\ Address for reprints: Fraser Douglas Rubens, MD, University of Ottawa Heart Institute, 40 Ruskin St, Room \\ H3401, Ottawa, Ontario K1Y 4W7, Canada (E-mail: frubens@ottawaheart.ca). \\ J Thorac Cardiovasc Surg 2017; 154:1587 \\ 0022-5223/\$36.00 \\ Copyright (C) 2017 by The American Association for Thoracic Surgery \\ http://dx.doi.org/10.1016/j.jtcvs.2017.07.052
}

\section{A light heart lives long.}

-William Shakespeare

Love's Labour's Lost, Act V, scene 2, line 18

This past week in my operating room, I nonchalantly mentioned that I had been asked to write an editorial about an interesting meta-analysis being published in this Journal looking at the relationship of depression and outcomes after cardiac surgery. I was not surprised when my colleagues queried whether the research reflected depression of the patients or a malady of the surgeon. Humor aside, their astonishment that preoperative depression was so common (a prevalence of $13.6 \%$ ) and that it had such a pronounced negative impact on long-term survival was reflective of the fact that this simple issue has not been taken seriously.

The study in this issue of the Journal by Flaherty and colleagues ${ }^{1}$ provides comprehensive evidence of the close association between preoperative depression and not only long-term survival but also long-term cardiac morbidity. Flaherty and colleagues ${ }^{1}$ have provided numerous postulates to help explain these robust relationships; the obvious include issues of depression's effect on compliance with drugs and exercise, but there are also several interesting arguments relating to potential biologic mechanisms. The relationship of depression to cardiac outcomes has been known, ${ }^{2}$ but this meta-analysis provides class I evidence to this bed of literature. This review provides support that screening for depression may be as important for development of postoperative strategies for secondary prevention as the assurance that patients are receiving statins, $\beta$-blockers, and aspirin. ${ }^{2}$ Although it is difficult to compare relative risks directly among meta-analyses of other similar interventions, the strong impact of depression of $50 \%$ or greater risk is worthy of all of us taking notice as a potential future strategy.

Love's Labour's Lost is a comedy touching on a variety of life topics, including romance, fickle love, reality, and

\section{References} 1578-86.e1. 131:927-64.

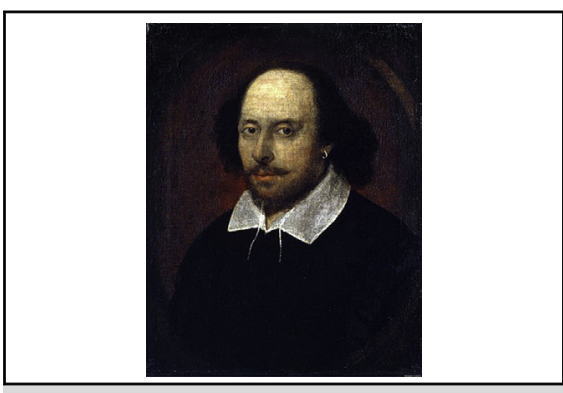

The Bard, the ultimate expert in human behavior.

Central Message

This meta-analysis highlights that depression must be embraced as a risk factor for deleterious outcomes after coronary surgery, highlighting our responsibility to broach this topic with patients.

See Article page 1578 .

fantasy, and it certainly is not about heart surgery. Yet it, like much of the Bard's writings, provides secular pearls of wisdom on how we should conduct our lives and deal with others. The playwright adds later in the scene, "A heavy heart bears not a nimble tongue." 3 This reminds us that patients may not proffer their mental state to their surgeons for fear of castigating themselves as weak complainers, so it remains our duty to delve into their mental well-being and offer compassion and help when needed. This study also serves to prompt us that there may be positive consequences for taking these steps, although at this point we have no absolute confirmation that treating the depression is proved to reverse these negative outcomes, and we must therefore wait for the next act.

1. Flaherty LB, Wood T, Cheng A, Khan AR. Preexisting psychological depression confers increased risk of adverse cardiovascular outcomes following cardiac surgery: a systematic review and meta-analysis. J Thorac Cardiovasc Surg. 2017; 154:

2. Kulik A, Ruel M, Jneid H, Ferguson TB, Hiratzka LF, Ikonomidis JS, et al American Heart Association Council on Cardiovascular Surgery and Anesthesia. Secondary prevention after coronary artery bypass graft surgery: a scientific statement from the American Heart Association. Circulation. 2015;

3. Shakespeare W. Love's Labour's Lost. Act V, scene 2, line 798. 